\title{
HALOTHANE SOLUBILITY IN BLOOD DURING CARDIOPULMONARY BYPASS: THE EFFECT OF HAEMODILUTION AND HYPOTHERMIA
}

\author{
Tsuneo Sada, Herbert T. Maguire, and J. Antonio Alorete
}

The SOLUBILITy of HALothane in blood is influenced by several factors such as lipid,' protein and haemoglobin concentrations, ${ }^{2}$ and haematocrit. During cardiopulmonary bypass two other factors may alter halothane solubility; these are hypothermia ${ }^{4.5 .6}$ and haemodilution.?

The purpose of this study was to determine the blood concentration and the, blood/gas partition coefficient of halothane during cardiopulmonary bypass with haemodilution in conditions of hypothermia and normothermia.

\section{MATERIALS AND METHOD}

The study included six patients undergoing open-heart surgery for the correction of congenital anomalies with mild hypothermia $\left(30^{\circ} \mathrm{C}\right)$ and six patients undergoing open-heart surgery for acquired heart diseases under normothermia $\left(36^{\circ}-37^{\circ} \mathrm{C}\right)$

A previously calibrated Fluotec Mark II vapourizer was inserted in line along the tubing delivering oxygen to a bubble oxygenator at a rate between 3 and $5 \mathrm{~L} / \mathrm{min}$ in the paediatric hypothermic cases and between 6 and $8 \mathrm{~L} / \mathrm{min}$ in the adult normothermic cases. Blood flow through the pump was maintained between 70 and $90 \mathrm{ml} \cdot \mathrm{kg}^{-1} \cdot \mathrm{min}^{-1}$ in the former and 50 to 70 $\mathrm{ml} \cdot \mathrm{kg}^{-1} \cdot \mathrm{min}^{-1}$ in the latter. Arterial blood gases and acid-base balance were kept within normal limits throughout the study. In both groups, two different concentrations of halothane were studied during cardiopulmonary bypass; first, a low concentration consisting of 0.6 per cent was given; then the high concentration administered

Tsunco Sada. M.D., Department of Anesthesiology. Kanazawa University, 13-I Takaramachi, Kanazawa, Ishikawa. Japan.

Herbert T. Maguire, M.D., Department of Anesthesiology, University of Louisville, 323 East Chestnut Street, Louisville, Kentucky 40201, U.S.A.

J. Antonio Aldrete, M.D., Department of Anesthesiology, University of Colorado, Medical Center, 4200 East Ninth Avenue, Denver, Colorado 80262. U.S.A. was 1.3 per cent, allowing for a ten-minute equilibration period.

Gas samples were collected in a $100 \mathrm{ml}$ glass sampling bulb described by Nicholson, et al. ${ }^{7}$ At the time of collection of the gas sample both stopcocks of the bulb were opened with the bulb inserted between the vapourizer and the bubble oxygenator. Initially the low concentration of halothane containing gas was passed through the bulb for ten minutes; thereafter, first the stopcock on the oxygenator side and then the stopcock on the vapourizer side were closed and the bulb was then removed from the line. Blood samples were drawn from the arterial side of the pump in a heparinized $5 \mathrm{ml}$ plastic syringe just before the stopcock of the gas sampling bulb on the oxygenator side was closed. Then the high concentration of halothane was turned on. Ten minutes later, gas and blood samples were collected in the same manner. Halothane concentrations in gas and blood were determined by gas chromatography as previously described.?

The haematocrit of all blood samples was measured using a Coulter Counter Model S, and the haemodilution rate was calculated prior to the surgical procedure. Whole blood and lactated Ringer's solution were used for priming the pump so that this rate would approximate 0.35 using the following formula:

$$
\text { Haemodilution rate }=\frac{\begin{array}{c}
\text { Lactated Ringer's in } \\
\text { the perfusate (Litres) }
\end{array}}{\begin{array}{c}
\text { Body weight }(\mathbf{k g}) \\
\times 0.08+\text { total } \\
\text { volume of perfusate } \\
\text { (Litres) }
\end{array}}
$$

In most cases, the haematocrit during cardiopulmonary bypass fell to approximately 25 per cent by this procedure. Also, throughout cardiopulmonary bypass, additional lactated Ringer's solution and whole blood were added to the pump to maintain perfusate volume, perfusion pressure and central venous pressure, as necessary.

To calculate the blood/gas ratio we conducted the following derivations: 
A. Estimation of the halothane concentration in the oxygenator.

This was achieved by estimating that one percent halothane vapour carried by the oxygen delivered from the vapourizer flowed into the oxygenator, where this dry gas was saturated with water vapour and warmed to $30^{\circ} \mathrm{C}$ or $37^{\circ} \mathrm{C}$ by a heat exchanger. Applying the ideal gas low, the amount of halothane in $100 \mathrm{ml}$ of fully humidified and warmed gas could be estimated as follows:

$$
\mathrm{PV}=\frac{\mathrm{H}}{\mathbf{M}} \mathrm{RT}
$$

where $P(a t m)$ : partial pressure of halothane, in reality,

$$
\mathrm{P}=\frac{\begin{array}{c}
760(\mathrm{~mm} \mathrm{Hg})-\text { Water vapour } \\
\text { pressure }(\mathrm{mm} \mathrm{Hg}) \text { at } \mathrm{t}^{\circ} \mathrm{C}
\end{array}}{760(\mathrm{~mm} \mathrm{Hg})} \times \frac{1(\%)}{100}
$$

$\mathrm{V}$ (litre); gas volume. $100 \mathrm{ml}$ is 0.1 litre.

$H$ (gram): the amount of halothane in $100 \mathrm{ml}$ of fully humidified oxygen at $t^{\circ} \mathrm{C}$ when one per cent of halothane was introduced to the oxygenator.

$M(g r a m)$ : molecular weight of halothane; 197.4

$$
\mathbf{R}\left(\frac{\text { litre-atm }}{\text { degree }}\right) \text { : gas constant; } 0.082
$$

$\mathrm{T}$ (degree): absolute temperature. At $\mathrm{t}^{\circ} \mathrm{C}, \mathrm{T}=$ $273+t$

Then

$$
\begin{aligned}
& H=\frac{\text { PVM }}{\text { RT }} \\
& 760 \text { - Water } \\
& \text { vapour pressure }
\end{aligned}
$$

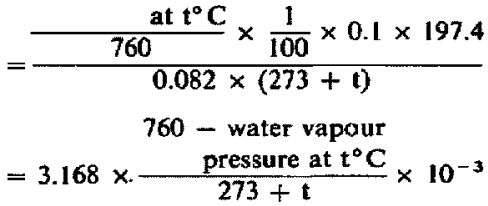

Since the water vapour pressures were $32 \mathrm{~mm}$ $\mathrm{Hg}(4.26 \mathrm{kPa})$ and $47 \mathrm{~mm} \mathrm{Hg}(6.25 \mathrm{kPa})$ at $30^{\circ} \mathrm{C}$ and $37^{\circ} \mathrm{C}$ respectively, therefore, $7.610 \mathrm{mg}$ and $7.285 \mathrm{mg}$ of halothane would be contained in 100 $\mathrm{ml}$ of fully humidified gas at $30^{\circ} \mathrm{C}$ and $37^{\circ} \mathrm{C}$ respectively, when one per cent of halothane was introduced to the oxygenator.
B. Calculation of blood/gas ratio.

Having obtained these results, the ratio of the amount of halothane in blood to the amount of halothane in gas was calculated as follows:

$$
\begin{aligned}
& \text { Halothane content in } 100 \mathrm{ml} \\
& \text { B/G }\left(30^{\circ} \mathrm{C}\right)=\frac{\text { of blood }(\mathrm{mg})}{7.610(\mathrm{mg} / 100 \mathrm{~m} \text { of gas }) \times} \\
& \text { halothane concentration (\%) } \\
& \text { delivered from vapourizer } \\
& \text { Halothane content in } 100 \mathrm{ml} \\
& \mathrm{B} / \mathrm{G}\left(37^{\circ} \mathrm{C}\right)=\frac{\text { of blood }(\mathrm{mg})}{7.285(\mathrm{mg} / 100 \mathrm{ml} \text { of gas }) \times} \\
& \text { halothane concen tration (\%) } \\
& \text { delivered from vapourizer }
\end{aligned}
$$

\section{Results}

The data obtained from our study are summarized in Table I: statistical analysis was conducted using the Student's t-test. The results of the statistical analysis are also shown in Table I.

There was no statistically significant difference in the concentrations of halothane delivered from the vapourizer at either 0.6 or 1.3 per cent when the hypothermic and normothermic groups were compared.

For the halothane concentration in blood, a statistically significant difference $(P<0.01)$ was obtained between the hypothermia and the normothermia groups.

As long as temperature was the same, the blood/gas ratio difference between the low and the high gas concentrations was not statistically significant; in other words, the blood/gas ratio was not influenced by the gas concentration. However, the blood/gas ralio between the hypothermic and normothermic groups was significantly different $(P<0.01)$ although the gas concentration was equal.

With regard to haematocrit changes, reflecting the degree of haemodilution, there were no significant differences between any of the groups of patients studied.

\section{Discussion}

Our observations indicate that solubility of halothane in blood was not markedly affected by changes of gas concentration, but was affected by temperature changes.

Lassberg and Hedley-White ${ }^{2}$ reported blood solubility $(\lambda)$ values for halothane at $30^{\circ} \mathrm{C}$ and 
TABLE I

\begin{tabular}{|c|c|c|c|}
\hline & $\begin{array}{c}\text { Hypothermic cases } \\
\left(30^{\circ} \mathrm{C}\right)\end{array}$ & $\begin{array}{l}\text { Normothermic cases } \\
\qquad\left(37^{\circ} \mathrm{C}\right)\end{array}$ & $\begin{array}{c}\text { Statistical } \\
\text { analysis }\end{array}$ \\
\hline $\begin{array}{l}\text { Gas concentration }(\%) \\
\text { Blood concentration }(\mathrm{mg} / 100 \mathrm{ml}) \\
\text { Blood/Gas ratio } \\
\text { Haematocrit }\end{array}$ & $\begin{array}{l}0.61 \pm 0.012 \\
10.2 \pm 1.65 \\
2.19 \pm 0.323 \\
25.3 \pm 3.52\end{array}$ & $\begin{aligned} 0.60 \pm 0.023 \\
5.9 \pm 0.861 \\
1.36 \pm 0.258 \\
26.5 \pm 2.84\end{aligned}$ & $\begin{array}{c}\text { NS } \\
\mathbf{S} \\
\mathbf{S} \\
\mathbf{N S}\end{array}$ \\
\hline $\begin{array}{l}\text { Gas concentration } \quad(\%) \\
\text { Blood concentration }(\mathrm{mg} / 100 \mathrm{ml}) \\
\text { Blood/Gas ratio } \\
\text { Haematocrit }\end{array}$ & $\begin{array}{l}1.34 \pm 0.036 \\
21.8 \pm 4.01 \\
2.14 \pm 0.395 \\
24.5 \pm 2.14\end{array}$ & $\begin{array}{l}1.25 \pm 0.155 \\
12.1 \pm 1.73 \\
1.33 \pm 0.105 \\
25.8 \pm 1.61\end{array}$ & $\begin{array}{l}\text { NS } \\
\mathbf{S} \\
\mathbf{S} \\
\mathbf{N S}\end{array}$ \\
\hline
\end{tabular}

NS: No significant difference between bypothermia and normothermia groups.

$S$ : Significant difference between hypothermia and normothermia groups $(P<0.01)$.

$37^{\circ} \mathrm{C}$ as 3.38 and 2.42 respectively. In our study, the mean values were 2.17 at $30^{\circ} \mathrm{C}$ and 1.34 at $37^{\circ}$ C. The difference is probably due to the fact that our blood samples had been diluted with lactated Ringer's solution used in the perfusate. ( $\lambda$ water 1.16 at $30^{\circ} \mathrm{C}$ and 0.78 at $37^{\circ} \mathrm{C}$ ).

The same authors have also shown that an increase in albumen concentration in blood or plasma increased the halothane partition coefficient; that is, when the concentration of albumen in plasma was increased by $4 \mathrm{mg} / 100 \mathrm{ml}$, the $\lambda$ value for halothane in plasma changed from 2.28 to 3.46 at $37^{\circ} \mathrm{C}$ and from 3.27 to 4.28 at $30^{\circ} \mathrm{C}$. A similar rise in globulin concentration in plasma caused a small decline of solubility coefficient. ${ }^{2}$

Ellis, et al..$^{3}$ reported a mean value of $\lambda$ for halothane of 2.60 with haematocrit of 42.6 per cent and 1.98 with haematocrit of 21.3 per cent, suggesting that in anaemic patients the $\lambda$ for halothane was 24 per cent lower. Similar results were shown by Lassberg, et $a l^{2}$ Our results are slightly different since the experimental conditions varied from those previously listed. Our data showed (Table I) an increase in blood/gas partition coefficient of 61 per cent with a fall in body temperature of $7^{\circ} \mathrm{C}$. In other words, there was an increase in halothane blood/gas partition coefficient of 8.7 for each degree Celsius. These changes are larger than those reported by Munson, et al. ${ }^{8}$ Han and Heldrick ${ }^{4}$ and Stoelting, et al. 9 who reported values around five per cent increase in the solubility per degree Celsius of temperature reduction.

More recently, the combined effects of hypothermia and haemodilution were studied by Feingold, ${ }^{10}$ who noted that the halothane blood/gas partition coefficient during simultaneous haemodilution and hypothermia undergoes little change, since the effects of the two factors are usually in opposite directions and they coun- teract each other. However, this prediction was estimated for haemodilution from 40 to 20 per cent haematocrit and a temperature fall from $37^{\circ}$ to $28^{\circ} \mathrm{C}$. In our study, haematocrits fell to about 25 per cent and temperature was lowered to $30^{\circ} \mathrm{C}$ only. Similarly, Feingold's samples were taken at an early phase of cardiopulmonary bypass (cooling) or near its end (rewarming), thus differing from our observations made during a more steady state of temperature, but at different halothane concentrations.

With this exception, the two studies complement one another and thus help to understand the pharmacokinetic changes observed during extracorporeal circulation.

\section{SUMMARY}

The influence of haemodilution and cooling on the solubility of halothane in blood during cardiopulmonary bypass was studied in six normothermic and six hypothermic patients undergoing open-heart operations. The solubility of halothane in blood was 2.17 at $30^{\circ} \mathrm{C}$ and 1.34 at $37^{\circ} \mathrm{C}$. There was also an increase in the blood/gas partition coefficient of about 8.7 per cent for each degree celsius of temperature fall.

These changes in haemodiluted blood explain the different anaesthetic requirements observed in patients undergoing cardiopulmonary bypass, either at normal temperature or at moderate hypothermia.

\section{RÉSUMÉ}

Les auteurs rapportent l'influence de l'hémodilution et du refroidissement durant la circulation extracorporelle sur la solubilité de l'halothane dans le sang. Six sujets normothermiques et six sujets hypothermiques était 
étudiés à l'occasion d'operation à coeur-ouvert. La solubilité de halothane était 2.17 à $30^{\circ} \mathrm{C}$ et 1.34 à $37^{\circ} \mathrm{C}$. On a aussi remarqué une augmentation du coefficient de solubilité de $8.7 \%$ pour chaque degré Celsius de diminuation de temperature.

Ces variations remarqués en hémodilution expliquent la variabilité des besoins anesthésiques observés lors de la circulation extracorporelle, en normothermie ou en hypothermie modéré.

\section{REFERENCES}

1. Lowe, H.J. \& Hagler, K. Delermination of volatile organic anesthetics in blood, gases, tissues, and lipid: partition coefficients. In Ciba Foundation symposium on gas chromatography and biology in medicine. Edited by R. Poter. London: J \& A Churchill, Ltd. pp. 86-103 (1969)

2. LAssberg, L.H. \& Hedley-Whyte, J. Halothane solubility in blood and solutions of plasma proteins; effects of temperature, protein composition and hemoglobin concentration. Anesthesiology 32: $351-356$ (1970).

3. El.tis, D.E. \& STOELTING, R.K. Individual variations in fluroxene, halothane, and methoxyflurane blood-gas partition coefficients and effect of anemia. Anesthesiology 42: 748-750 (1975).

4. HAN, Y.H. \& HELRICH, M. Effect of body temperature on anesthetic blood levels of halothane in man. Anesthesiology 27: 217-218 (1966).

5. AlLOT, P.R. STEWARD, A. Flook, V \& MAPLESON, W.W. Variation with temperature of the solubilities of inhaled anesthetics in water, oil and biological media. Brit. J. Anaesth. 45: 282-293 (1973).

6. Yoxota, T. Concentration of halothane in blood during extracorporeal circulation. Jap. J. Anesth. 17: 33-39 (1968).

7. Nicholson, J.A., Sada, T., \& Aldrete, J.A. Residual halothane: putient and personnel exposure. Anesth. Analg. 54: 449-454 (1975).

8. Munson, E.S., Saidman, L.T., \& Eger, E.I. Solubility of fluroxene in blood and tissue homogenate. Anesthesiology 25: 638-640 (1964).

9. Stoelting, R.K. \& Longshore, R.E. The effect of temperature on fluroxene, halothane and methoxyflurane blood-gas and cerebrospinal fluid-gas partition coefficients. Anesthesiology 36: 503-505 (1972).

10. Feingold, A. Crystalloid hemodilution, hypothermia and halothane blood solubility during cardiopulmonary bypass. Anesth. Analg. 56: 622-626 (1977). 